\title{
PENGEMBANGAN PERANGKAT PEMBELAJARAN MENGGUNAKAN MODEL INKUIRI TERBIMBING TOPIK KLASIFIKASI MAKHLUK HIDUP DI SMP
}

\author{
Erma Yunita \\ SMP Negeri 2 Sungai Tabuk Kab. Banjar \\ Email : yunitae14@yahoo.co.id
}

\begin{abstract}
ABSTRAK
Perangkat pembelajaran di sekolah terdiri dari silabus, RPP, LKS, bahan ajar, media dan instrumen penilaian. Berdasarkan hasil supervisi klinis masing-masing komponen perangkat belum mengarah pada keterampilan berpikir siswa sesuai dengan kurikulum 2013. Model pembelajaran yang digunakan belum sepenuhnya berpusat pada siswa. Penelitian ini bertujuan untuk menghasilkan perangkat pembelajaran hasil pengembangan topik klasifikasi makhluk hidup menggunakan model pembelajaran inkuiri terbimbing di SMP yang valid, praktis dan efektif. Jenis penelitian ini merupakan penelitian \& pengembangan, menggunakan model ASSURE, namun hanya sampai evaluasi formatif saja. Subyek penelitian pada berbagai uji coba siswa kelas VII SMP Negeri Sungai Tabuk. Data diperoleh menggunakan berbagai instrumen melalui tes dan pengamatan. Analisis data dilakukan secara deskriptif. Hasil penelitian menunjukkan perangkat pembelajaran tergolong valid berdasarkan 1) rata-rata penilaian pakar sebesar 79,11\% dengan kategori cukup valid dan 2) uji keterbacaan bahan ajar sebesar 75\% dengan kategori baik dan LKS 100\% dengan kategori sangat baik. Praktis berdasarkan 1) keterlaksanaan RPP mencapai 3,72 tergolong kategori sangat baik. 2) respon positif siswa terhadap proses pembelajaran mencapai 93\%. Efektif berdasarkan 1) hasil belajar kognitif produk dan kognitif prosestuntas melebihi batas ketuntasan 75\% yaitu 78,26\%. 2). Hasil kinerja proses rata-rata 93,67\% tergolong kategori sangat baik, 3) Kinerja psikomotor mencapai 96,4\% tergolong kategori sangat baik, 4) Sikap spiritual (rasa syukur), 5) Perilaku berkarakter (disiplin, dan tanggung jawab), dan 6) Keterampilan sosial mencapai 100\% tergolong kategori sangat baik, 7) Keterampilan berpikir kritis siswa mencapai 88,93\% tergolong kategori sangat baik dan hasil belajar LKS sebesar 91,4\% tergolong kategori sangat baik, 8) Aktivitas siswa $\geq 10 \%$ tergolong kategori baik, siswa aktif dalam proses pembelajaran dan 9) Aktivitas guru $\leq 10 \%$ tergolong kategori baik, keterlibatan guru dalam pembelajaran mulai mengalami peningkatan.
\end{abstract}

Kata kunci: perangkat pembelajaran, klasifikasi makhluk hidup, inkuiri terbimbing

\begin{abstract}
Learning media in the school is consisting of syllabus, lesson plan, workbook, material, media, and assesment instrument. Based on the clinical supervision on each components, the media are not yet covering the cognitive skill of the students based on the curriculum 2013 that the applied learning model is not yet student centered. The research is purposed to design a valid, practical, and effective learning media as a result from the clarification of organism topic using guided enquiry learning topic in junior high school. The type of the research is a research and development using ASSURE model limited to the formative evaluation. The subject of the research is several test on the seventh grade students of Sungai Tabuk Junior High School. The data is collected by using several instruments of test and observations. The data analysis is conducted through descriptive method. The result of the research showed the validity of the learning media based on 1) the average score $79,11 \%$ from the validity experts, and
\end{abstract}


2) readable learning material of $75 \%$ with good category and workbook of $100 \%$ with very good category. The practice based on 1) Accomplished lesson plan of 3.72 with very good category. 2) Positive respond from the students on the learning process with score 93\%. Effectiveness based on 1) The product of cognitive learning and process with score $78.26 \%$ is exceeding the $75 \%$ limit of accomplishment. 2) The average work process is 93.67\% with very good category, 3) Psychomotor work is $96.4 \%$ with very good category, 4) Spiritual attitude, 5) Character attitude (discipline and responsibility), and (6) Social skill is on $100 \%$ value with very good category, 7) Student's critical thinking is $88,93 \%$ with very good category and workbook learning result is $91.4 \%$ with very god category, 8) students' activity is $\geq 10 \%$ with good category, the students are involved actively in the learning process, and 9) teacher's activity is $\leq 10 \%$ with good category, the teacher involvement is showing progress.

Keywords: Learning media, classifications of organism, guided enquiry

\section{PENDAHULUAN}

Standar proses adalah kriteria mengenai pelaksanaan pembelajaran pada satuan pendidikan untuk mencapai Standar Kompetensi Lulusan. Standar Kompetensi Lulusan (SKL) dan Standar Isi (SI) menjadi landasan untuk mengembangkan standar proses. Proses pembelajaran pada satuan pendidikan diselenggarakan secara interaktif, inspiratif, menyenangkan, menantang dan memotivasi siswa untuk aktif (Permendikbud No. 65 Tahun 2013). Untuk meningkatkan efesiensi dan efektivitas ketercapaian kompetensi lulusan diperlukan perencanaan pembelajaran, pelaksanaan proses pembelajaran dan penilaian proses pembelajaran sesuai dengan standar proses.

Salah satu keterampilan berpikir adalah keterampilan berpikir kritis. Menurut Ennis (2011) berpikir kritis adalah berpikir masuk akal untuk mengambil keputusan. Snyder \& Snyder (2008) menyatakan keterampilan berpikir memerlukan instruksi dan praktik dalam pembelajaran. Menurut Scriver \& Paul seperti dikutip Ennis (2011) berpikir kritis merupakan keterampilan berpikir yang berpusat pada hasil analisis, mengevaluasi informasi yang dihasilkan melalui pengamatan, pengalaman, refleksi, penalaran atau komunikasi. Hal demikian menunjukkan bahwa keterampilan berpikir siswa perlu ditingkatkan dalam proses pembelajaran.

Perangkat pembelajaran di sekolah terdiri atas silabus, RPP, LKS, bahan ajar, media, dan instrumen penilaian. Berdasarkan hasil survei supervisi klinis perangkat pembelajaran di SMPN 2 Sungai Tabuk menunjukkan komponen perangkat pembelajaran yang terdiri dari silabus, RPP, dan LKS sudah dibuat akan tetapi komponen perangkat belum dikembangkan sesuai dengan Kurikulum 2013. Perangkat pembelajaran yang digunakan belum mengarah pada keterampilan berpikir siswa. Model pembelajaran yang digunakan selama proses pembelajaran belum bervariasi, sehingga pembelajaran belum berpusat pada siswa (student center). Hal ini menjadi dasar dilakukan pengembangan perangkat pembelajaran untuk melatih keterampilan berpikir siswa.

Perangkat pembelajaran yang dimaksud menurut Permendikbud No. 65 Tahun 2013 terdiri atas komponenkomponen dalam bentuk buku. Perangkat pembelajaran yang mengikuti langkahlangkah pengembangan diharapkan menghasilkan perangkat pembelajaran 
yang valid, praktis dan efektif. Berdasarkan hal tersebut, maka salah satu solusinya dengan mengembangkan perangkat pembelajaran menggunakan model pembelajaran yang dapat menggali keterampilan berpikir siswa. Model pembelajaran yang digunakan adalah model inkuiri terbimbing. McBride, dkk. (2004) menyatakan bahwa inkuiri merupakan suatu proses dimana siswa secara aktif menyelidiki atau meneliti melalui kegiatan bertanya dan mencari jawaban untuk pertanyaan-pertanyaan yang mereka ajukan. Martin \& Hansen (2002) menambahkan inkuiri membutuhkan pengenalan anggapan-anggapan, penggunaan cara berpikir kritis, logis dan penjelasan alternatif. Matthew \& Konneth (2013) juga menambahkan bahwa model pembelajaran inkuiri terbimbing dapat memberikan siswa kesempatan belajar berpikir kritis pada proses kinerja ilmiah. Pembelajaran menggunakan model inkuiri terbimbing tersebut dapat membuat siswa berinteraksi dan menjadi lebih aktif dalam kegiatan pembelajaran.

Berdasarkan uraian tersebut, maka perlu dilakukan suatu penelitian pengembangan perangkat pembelajaran menggunakan model inkuiri terbimbing topik Klasifikasi Makhluk Hidup di SMP yang valid, praktis, dan efektif. Hasil penelitian tersebut diharapkan relevan dengan Permendikbud No. 65 Tahun 2013.

\section{METODE PENELITIAN}

Penelitian dan pengembangan ini mengembangkan perangkat pembelajaran yang meliputi silabus, RPP, bahan ajar, LKS, kunci LKS, lembar penilaian, dan media. Langkah-langkah pengembangan menggunakan model ASSURE meliputi:
Analyze Learners, State Objectives, Select Methods, Media \& Material, Utilize media and materials, Require Learner Participation, Evaluate and revise.

Penelitian ini dilaksanakan di SMP Negeri 2 Sungai Tabuk. Subyek coba penelitian perorangan dari tim ahli melibatkan 3 orang dosen sesuai bidang kepakarannya. Subyek coba dari kalangan siswa pada uji perorangan berasal dari siswa kelas VIIE, Subyek uji coba kelompok kecilberasal dari siswa kelas VIIC, dan subyek coba uji lapangan berasal dari kelas VIID. Data kelayakan perangkat pembelajaran berdasarkan hasil uji perorangan meliputi validasi ahli (Expert review) dan uji keterbacaan siswa. Data untuk menetapkan kepraktisan perangkat pembelajaran berdasarkan data: keterlaksanaan Rencana Pelaksanaan Pembelajaran dan respon siswa. Data untuk menetapkan keefektivan perangkat pembelajaran berdasarkan: 1) hasil belajar kognitif, 2) kinerja proses, 3) kinerja psikomotor, 4) sikap spiritual, 5) perilaku berkarakter, 6) sikap sosial, 7) keterampilan berpikir kritis siswa, 8) aktivitas siswa, 9) data aktivitas guru. Semua data yang didapatkan dianalisis secara deskriptif.

\section{HASIL DAN PEMBAHASAN}

Perangkat pembelajaran hasil pengembangan topik Klasifikasi Makhluk Hidup dinilai kevalidan oleh 3 orang tim ahli validasi yang telah ditetapkan. Perangkat pembelajaran hasil validasi ahli (Expert Review) tersebut kemudian direvisi sesuai saran validator. Hasil validasi tim ahli dapat dilihat pada Tabel 1. 
Tabel 1. Hasil Validasi Perangkat Pembelajaran

\begin{tabular}{|c|c|c|c|c|c|}
\hline \multirow{2}{*}{$\begin{array}{c}\text { Perangkat } \\
\text { Pembelajaran }\end{array}$} & \multicolumn{3}{|c|}{ Saran Validator $(\%)$} & \multirow{2}{*}{$\begin{array}{l}\text { Skor rata- } \\
\text { rata validasi }\end{array}$} & \multirow{2}{*}{ Kriteria } \\
\hline & V1 & V2 & V3 & & \\
\hline Silabus & 77,5 & 97,5 & 82,5 & 85,83 & Sangat Valid \\
\hline RPP & 62,5 & 84,45 & 75 & 73,98 & Cukup Valid \\
\hline Bahan Ajar & 82,5 & 85 & 75 & 75,64 & Cukup Valid \\
\hline $\begin{array}{l}\text { Media } \\
\text { Pembelajaran }\end{array}$ & 66 & 82,81 & 78,12 & 80,83 & Cukup Valid \\
\hline LKS & 66 & 87,5 & 77,5 & 77 & Cukup Valid \\
\hline LP 1 Produk & 81,25 & 68,75 & 75 & 75 & Cukup Valid \\
\hline LP 2 Proses & 81,25 & 93,75 & 75 & 83,33 & Cukup Valid \\
\hline LP 3 Psikomotor & 81,25 & 68,75 & 75 & 75 & Cukup Valid \\
\hline $\begin{array}{l}\text { LP } 7 \text { Keterampilan } \\
\text { berpikir kritis }\end{array}$ & 81,25 & 100 & 75 & 85,42 & Cukup Valid \\
\hline
\end{tabular}

Sumber : hasil pengolahan data

Validator : V1 = Prof. Dr. Endang Susantini, M.Pd., V2 = Drs. H. Aminuddin PP, M.Pd. dan V3=Ayatusa”adah, M.Pd.

Kategori : 85,01-100,00\% ( Sangat valid), 70,01 - 85,00\% ( Cukup valid), 50,01 - 70,00\% (Kurang valid), 01,00 - 50,00\% (Tidak valid),

Perangkat pembelajaran yang telah oleh 6 orang siswa SMPN 2 Sungai Tabuk divalidasi seperti Tabel 1 tergolong cukup Kelas VIIE. Uji perorangan disajikan pada valid, dan ini sudah layak digunakan dengan Tabel 2.

direvisi kecil. Uji perorangan dilakukan

Tabel 2. Hasil penilaian Siswa Terhadap Bahan Ajar dan LKS

\begin{tabular}{lcc}
\hline Penilaian Siswa & $\Sigma$ Skor rata-rata & Kategori \\
\hline Bahan Ajar & $75 \%$ & Cukup baik \\
LKS & $100 \%$ & Sangat baik \\
\hline
\end{tabular}

Sumber : hasil pengolahan data

Kategori : sangat baik (86-100\%), baik (76-85\%), cukup (60-75\%), kurang (55-59\%) dan kurang sekali $(<54 \%)$.

Tabel 2 menunjukkan data penilaian dan LKS layak digunakan untuk tahap bahan ajar dan LKS menurut siswa pada uji perorangan direspon secara positif. Hal ini menunjukkan bahan ajar kepraktisan, disajikan pada Tabel 3.

Tabel 3. Keterlaksanaan Rencana Pelaksanaan pembelajaran

\begin{tabular}{|c|c|c|c|c|c|c|}
\hline \multirow[b]{2}{*}{ Tahapan } & \multicolumn{4}{|c|}{ Skor Pertemuan Ke- } & \multirow{2}{*}{$\begin{array}{c}\Sigma \text { Skor } \\
\text { rata- } \\
\text { rata }\end{array}$} & \multirow[b]{2}{*}{ Kategori } \\
\hline & 1 & 2 & 3 & 4 & & \\
\hline Pendahuluan & 3.6 & 3,8 & 3.8 & 3,8 & 3.8 & Sangat baik \\
\hline Kegiatan Inti & 3,6 & 3,7 & 3,6 & 3,7 & 3,7 & Sangat baik \\
\hline Penutup & 3.75 & 3,75 & 3.75 & 3.75 & 3.8 & Sangat baik \\
\hline Rata-rata & 3,7 & 3,8 & 3,7 & 3,8 & 3,7 & Sangat baik \\
\hline
\end{tabular}

Sumber : Hasil pengolahan data

Erma Yunita, Pengembangan Perangkat Pembelajaran Menggunakan Model Inkuiri Terbimbing Topik Klasifikasi Makhluk Hidup di SMP 
Kategori: Kurang sekali $=0-1,5 \quad$ Kurang $=1,6-2,5 \quad$ Baik $=2,6-3,5 \quad$ Sangat baik $=3,6-4,0$

Parameter keterlaksanaan RPP Keterangan: 1: tidak dilakukan sama sekali (tidak baik), 2: dilakukan sebagian kecil (kurang baik), 3: dilakukan sebagian sesuai prosedur (baik), 4: dilakukan sesuai prosedur (sangat baik)

Tabel 3 menunjukkan bahwa ketiga dengan baik. Respon siswa mengikuti tahapan dalam RPP, yaitu pendahuluan, pembelajaran diperoleh di akhir pertemuan kegiatan inti, dan penutup telah terlaksana dapat dilihat pada Tabel 4

Tabel 4. Respon Siswa terhadap Pembelajaran

\begin{tabular}{|c|c|c|c|c|c|}
\hline Uji Coba & Respon Posit if & Skor & Total Skor & Rata-rata & Respon Positif Siswa \\
\hline Kelas VII D & SS & 600 & & & \\
\hline \multirow[t]{4}{*}{ (12 Siswa) } & $\mathrm{S}$ & 484 & & & \\
\hline & RR & 32 & 1116 & 93 & \\
\hline & TS & 0 & & & \\
\hline & STS & 0 & & & \\
\hline
\end{tabular}

Sumber : Hasil pengolahan data

Kategori : sangat baik (86-100\%), baik (76-85\%), cukup (60-75\%), kurang (55-59\%) dan kurang sekali $(<54 \%)$.

Tabel 4 menunjukkan bahwa siswa memberikan respon positif terhadap kegiatan pembelajaran.

Uji lapangan dilakukan pada kelas VIIC yang terdiri dari 23 orang siswa yang dilaksanakan empat kali pertemuan. Hasil keefektivan perangkat pembelajaran pada uji lapangan yaitu hasil belajar kognitif produk dan proses yang disajikan pada Tabel 5.

Tabel 5. Ringkasan Data Ketuntasan Klasikal

\begin{tabular}{ccccccc}
\hline \multirow{2}{*}{ Sumber } & $\begin{array}{c}\text { Skor } \\
\text { Maksimal }\end{array}$ & Tuntas & \begin{tabular}{c} 
Tidak \\
\cline { 3 - 4 } Tuntas
\end{tabular} & Jumlah & $\begin{array}{c}\text { \% Tuntas } \\
\text { Klasikal }\end{array}$ & Rata-rata \\
\cline { 3 - 4 } Pre Test & 100 & 0 & 23 & 23 & 0 & 0 \\
Post Test & 100 & 18 & 5 & 23 & 78.26 & 78.261 \\
\hline
\end{tabular}

Sumber : Hasil pengolahan data

Ketentuan : Kriteria Ketuntasan Minimal (KKM), yaitu untukketuntasan individual > 70 tergolong tuntas secara individual dan untuk ketuntatasan $>75$ klasikal tergolong tuntas secara klasikal.

Tabel 5 menunjukkan bahwa secara klasikal hasil belajar siswa pada postest ternyata ada 18 orang (melampaui KKM).
Hasil kinerja proses siswa diperoleh dari rincian tugas kinerja yang dilakukan oleh siswa selama proses pembelajaran. Secara ringkas disajikan pada Gambar 1. 


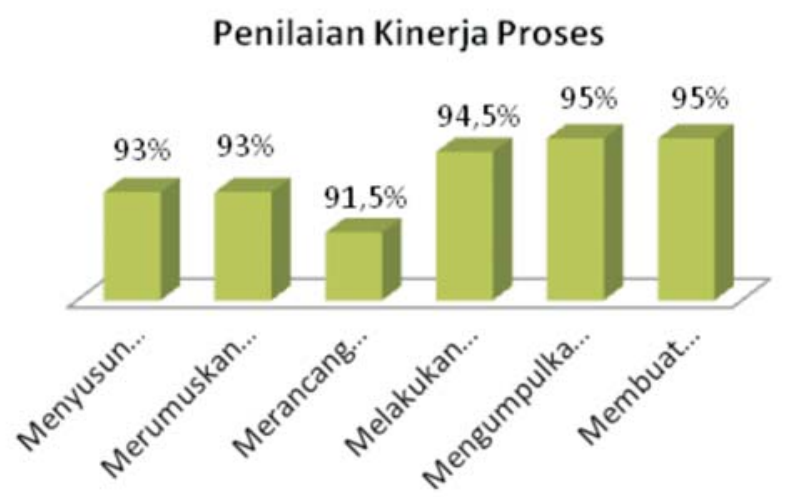

Gambar 1. Hasil Kinerja Proses

Gambar 1 menunjukkan bahwa kinerja yang dilakukan oleh siswa selama proses proses seluruh kelompok mencapai pembelajaran. Secara ringkas disajikan persentase di atas 90\%. Hasil penilaian pada Gambar 2.

psikomotor diperoleh dari rincian tugas

\section{Penilaian Kinerja Psikom otor}

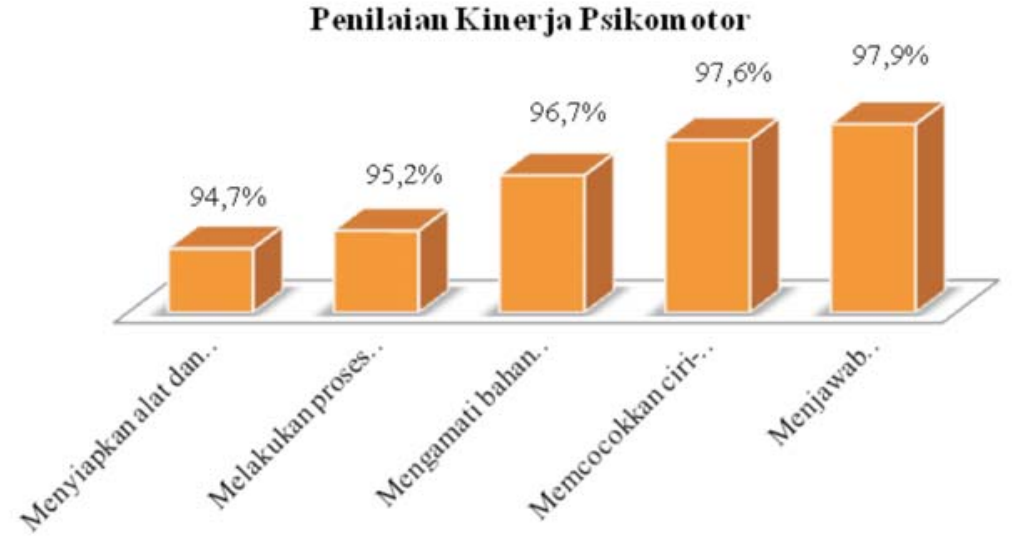

Gambar 2. Hasil Kinerja Psikomotor

Gambar 2 menunjukkan bahwa kinerja psikomotor seluruh kelompok rata-rata mencapai kategori sangat baik. Sikap spiritual siswa yang diamati melaluis rasa syukur pada saat pembelajaran dengan kategori sangat baik.

Perilaku berkarakter siswa berupa disiplin dan tanggungjawab rata-rata mencapai $100 \%$ juga dengan kategori sangat baik. Keterampilan sosial siswa yang diamati melalui bekerjasama dan komunikasi lisan selama proses pembelajaran berlangsung kategori sangat baik.

Keterampilan berpikir kritis siswa dalam proses pembelajaran diperoleh dari kemampuan siswa dalam mengerjakan LKS secara berkelompok. Penilaian keterampilan berpikir kritis disajikan pada Tabel 6. 
Tabel 6. Ringkasan Hasil Keterampilan Berpikir Kritis

\begin{tabular}{|c|c|c|c|c|c|c|c|c|}
\hline \multirow{2}{*}{ Kelompok } & \multicolumn{6}{|c|}{ Parameter } & \multirow{2}{*}{ Rata-rata \% } & \multirow{2}{*}{ Kategori } \\
\hline & 1 & 2 & 3 & 4 & 5 & 6 & & \\
\hline 1 & 9,13 & 9,25 & 19 & 22,5 & 19,3 & 10,8 & 89,98 & sangat baik \\
\hline 2 & 9,13 & 10 & 19 & 21,5 & 19,3 & 10,8 & 78,93 & baik \\
\hline 3 & 9,25 & 9,25 & 19,23 & 21,5 & 19,3 & 11,9 & 90,5 & sangat baik \\
\hline 4 & 10 & 10 & 22 & 21,5 & 20 & 12 & 95,5 & sangat baik \\
\hline Rata-rata & 9,38 & 9,63 & 19,83 & 21,75 & 19,4 & 11,38 & $88,93 \%$ & sangat baik \\
\hline
\end{tabular}

Sumber : Hasil pengolahan data

Kategori : sangat baik (86-100\%), baik (76-85\%), cukup (60-75\%), kurang (55-59\%) dan kurang sekali ( $<54 \%)$.

Parameter: 1) merumuskan masalah, 2) merumuskan hipotesis, 3) merancang pengamatan, 4) melakukan pengamatan, 5) mengumpukan data dan 6) merumuskan kesimpulan

Tabel 6 menunjukkan rata-rata penilaian aktivitas siswa disajikan keterampilan berpikir siswa sebesar pada Tabel 7 . 88,93\% tergolong sangat baik. Hasil

Tabel 7. Ringkasan Hasil Aktivitas Siswa Uji Lapangan

\begin{tabular}{lcccccccc}
\hline \multirow{2}{*}{ Nama Siswa } & 1 & 2 & 3 & 4 & 5 & 6 & 7 & 8 \\
\hline$\%$ & 10 & 11,1 & 10,9 & 10,8 & 15 & 21,4 & 10,3 & 10,1 \\
Kategori & $\mathrm{R}$ & $\mathrm{T}$ & $\mathrm{T}$ & $\mathrm{T}$ & $\mathrm{T}$ & $\mathrm{T}$ & $\mathrm{T}$ & $\mathrm{T}$ \\
\hline
\end{tabular}

Sumber: Hasil pengolahan data

Kategori: $<10 \%$ rendah (buruk), $>10 \%$ tinggi (baik); $(\mathrm{T}=$ Baik dan $\mathrm{R}=$ Buruk).

Keterangan parameter:

1. Siswa mendengarkan penjelasan guru

2. Siswa membuat pertanyaan penelittian

3. Siswa mengajukan pertanyaan dan membuat rumusan masalah di LKS

4. Siswa membuat hipotesis atau jawaban sementara

5. Siswa membuat prosedur kerja (langkah-langkah pengamatan)

6. Siswa melakukan pengamatan sesuai dengan prosedur kerja dan mencatat hasil pengamatan

7. Siswa melakukan presentasi jawaban LKS

8. Siswa membuat kesimpulan

Tabel 7 menunjukkan aktivitas siswa tergolong baik, kecuali mendengarkan

Ringkasan hasil penilaian tehradap penjelasan guru yang masih memerlukan perbaikan. aktivitas guru disajikan pada Tabel 8 . 
Tabel 8. Ringkasan Hasil Aktivitas Guru pada Kegiatan Pembelajaran

\begin{tabular}{cccccccccc}
\hline & \multicolumn{1}{c}{ Parameter } & \multicolumn{2}{c}{ ? } \\
& 1 & 2 & 3 & 4 & 5 & 6 & 7 & 8 & \\
\hline$\%$ & 9.5 & 13.4 & 10 & 10 & 16.1 & 20.1 & 10.8 & 10 \\
Kategori & $\mathrm{R}$ & $\mathrm{T}$ & $\mathrm{R}$ & $\mathrm{R}$ & $\mathrm{T}$ & $\mathrm{T}$ & $\mathrm{T}$ & $\mathrm{R}$ & \\
\hline
\end{tabular}

Sumber: Hasil pengolahan data

Kategori: < 10\% rendah (baik), > 10\% tinggi (buruk); $\mathrm{T}=$ Buruk dan $\mathrm{R}=$ Baik).

Keterangan parameter:

1. Guru membuka pelajaran, presensi siswa, memberikan apersepsi, dan motivasi serta menyampaikan tema pembelajaran dan IPK

2. Guru menyampaikan sedikit materi pengantar sesuai dengan tema yang akan dipelajarai

3. Guru membimbing siswa mengidentifikasi masalah. Guru membagi siswa dalam kelompok

4. Guru membimbing siswa dalam menentukan hipotesis yang relevan dengan permasalahan dan memperioritaskan hipotesis mana yang akan dibuktikan

5. Guru memberikan kesempatan kepada siswa untuk menentukan langkah-langkah yang akan dilakukan sesuai dengan hipotesis yang dibuat. Guru membimbing mengurutkan langkahlangkah pengamatan.

6. Guru membimbing siswa mendapatkan informasi melalui pengamatan

7. Guru memberikan kesempatan kepada tiap kelompok untuk menyampaikan hasil pengolahan data yang terkumpul

8. Guru membimbing siswa untuk melakukan refleksi

Tabel 8 menunjukkan guru masih mendominasi selama pembelajaran, dan hal seperti ini perlu mendapat perhatian. Sekalipun demikian tandatanda guru mengurangi aktivitasnya sudah nampak.

Berdasarkan hasil penelitian yang dipaparkan di atas, perangkat pembelajaran dikatakan valid berdasarkan pendapat tim pakar dan siswa mampu memahami bahan ajar dan LKS oleh siswa. Perangkat pembelajaran dikatakan praktis karena guru mampu melaksanakan pembelajaran dengan baik dan siswa memberikan respon positif terhadap pembelajaran. Perangkat pembelajaran dikatakan efektif berdasarkan beberapa idikator yang tergolong kategori baik yakni hasil belajar kognitif produk dan kognitif proses, kinerja proses, kinerja psikomotor, sikap spiritual (rasa syukur), perilaku berkarakter (disiplin, dan tanggungjawab), keterampilan social, keterampilan berpikir kritis, hasil belajar LKS, aktivitas siswa, dan aktivitas guru.

Validitas produk merupakan salah satu high quality intervension. Akker dkk. (2007) menyatakan validitas adalah salah satu kriteria yang menentukan kualitas suatu produk. Menurut Suwartaya (2013) perangkat pembelajaran dapat dikatakan valid apabila minimal memenuhi kategori validitas dengan rata-rata nilai minimal yang ditetapkan.

Perangkat pembelajaran dikatakan praktis berdasarkan pengakuan guru dan siswa. Guru mulai terbiasa menggunakan langkah-langkah model inkuiri terbimbing dalam pembelajaran. Menurut Smaldino, dkk. (2011) perencanaan dengan cermat, melibatkan siswa dalam kegiatan pembelajaran akan mewujudkan pembelajaran yang efektif. Di kalangan siswa melalui uji perorangan, mereka memberikan tanggapan yang sangat baik terhadap pembelajaran. Dewi, dkk. 
(2013) melaporkan bahwa respon siswa terhadap pembelajaran menggunakan model inkuiri terbimbing tergolong praktis.

Perangkat pembelajaran efektif berdasarkan beberapa indicator yang teramati. Opara \& Oguzor (2011) menyatakan prestasi akademik siswa dalam pembelajaran biologi meningkat melalui penyelidikan menggunakan inkuiri. Penelitian ini didukung Schaal, dkk (2012) yang menyatakan bahwa hasil pembelajaran keanekaragaman hayati di lapangan berbasis inkuiri menunjukkan bukti keberhasilan belajar dan memberikan pengalaman kepada siswa. Menurut McBride, dkk. (2004) pembelajaran menggunakan inkuiri dapat membantu siswa belajar ilmu pengetahuan melalui tahapan proses penyelidikan secara mandiri. Senada dengan pendapat Hamdani (2010) yang mengemukakan bahwa inkuiri sebagai salah satu model yang bersifat memecahkan masalah dengan cara kritis, analisis dan ilmiah dengan menggunakan langkah-langkah tertentu menuju kesimpulan sesuai dengan data.

Kong \& Winnie So (2008) menyatakan model inkuiri terbimbing dapat mendorong siswa melakukan kinerja psikomotor. Khumairo (2014) model pembelajaran Guided Inquiry disertai Mind Mapping berpengaruh terhadap hasil belajar spiritual Biologi siswa yang memiliki kemampuan akademik berbeda. Menurut Rooney (2012) penggunaan model inkuiri menunjukkan sikap positif pada pembelajaran matematika.

Aunurrahman (2013) menjelaskan bahwa pengetahuan dihasilkan dari kegiatan mengumpulkan informasi melalui interaksi sosial antara siswa dengan guru dan antar siswa. Pengetahuan dibangun pada saat siswa melakukan interaksi dengan lingkungan dan proses perubahan individu dengan lingkungan. Martin \& Hansen (2002) menjelaskan inkuiri berkenaan dengan kerja/karya para ahli pengetahuan dalam pembelajaran dalam mengajukan penjelasan yang terkumpul berdasarkan bukti. Inkuiri meliputi aktivitas siswa seperti bertanya, merencanakan penyelidikan dan meninjau keterangan yang telah diketahui dengan jelas dari bukti percobaan.

Menurut Berry \& Berry (2014) pembelajaran menggunakan model inkuiri dapat meningkatkan keterlibatan dan menghasilkan pembelajaran yang bermakna. Menurut Martin \& Hansen (2002) penggunaan inkuiri terbimbing dalam proses penyelidikan memerlukan bimbingan dari guru untuk memecahkan masalah. Temuan ini didukung penelitian Dewi, dkk. (2013) yang menyatakan melalui model inkuiri terbimbing siswa dibimbing untuk mengetahui pengetahuan melalui pengalaman secara langsung.

\section{SIMPULAN}

Penelitian dan pengembangan ini telah berhasil mengembangkan perangkat pembelajaran topik klasifikasi makhluk hidup menggunakan model pembelajaran inkuiri terbimbing di SMP yang layak (valid), praktis dan efektif. 1. Dikatakan valid berdasarkan: a. Hasil validasi ahli (expert review) yang menunjukkan semua perangkat pembelajaran mencapai $79,11 \%$ tergolong cukup valid, dan b. Hasil uji keterbacaan perorangan yaitu bahan ajar sebesar $75 \%$ dengan kategori baik dan LKS 100\% dengan kategori sangat baik. 2. Praktis berdasarkan hasil uji kelompok kecil berdasarkan a. Keterlaksanaan RPP mencapai 3,72 tergolong sangat baik, dan b. Respon positif siswa terhadap 
pembelajaran mencapai 93\%. 3. Efektif berdasarkan hasil uji lapangan: a. Hasil belajar kognitif produk mencapai 75,43\% menunjukkan siswa telah mencapai ketuntasan individual, b. Kinerja proses siswa mencapai 93,82\% tergolong sangat baik, c. Kinerja psikomotor siswa ratarata mencapai 96,16\% tergolong sangat baik, d. Kinerja sikap spiritual siswa ratarata mencapai $100 \%$ tergolong sangat baik, e. Perilaku berkarakter siswa (disiplin dan tanggungjawab) mencapai 100\% didominasi kategori sangat baik, $f$. Keterampilan sosial siswa (bekerjasama dan komunikasi lisan) yang mencapai 100\% didominasi kategori sangat baik, g. Keterampilan berpikir kritis siswa pada kegiatan merumuskan masalah, membuat jawaban sementara, membuat prosedur pengamatan, melakukan pengamatan dan membuat kesimpulan rata-rata mencapai 94\% tergolong kategori sangat baik, $h$. Keaktifan siswa menonjol pada 7 dari 8 parameter aktivitas siswa, i. guru telah mampu mengurangi keaktifannya pada 4 dari 8 parameter dalam kegiatan pembelajaran.

\section{DAFTAR PUSTAKA}

Akker, Jan van den, Brenda Bannan, Anthony E. Kelly, Nienke Nieveen \& Tjeerd Plomp. 2007. “An Introduction to Educational Design Research. Proceedings of the seminar conducted at the East China Normal University, Shanghai (PR China)”. Enschede the Netherlands: Netzodruk, Enschede. November, 2007. 23-26.

Bery, M.H. \& Berry, G. 2014.”Reading An Object: Developing Effective scientific Inquiry Using Student Quistions" European Journal Of Science And Mathematics Education. 2(2) 87-97.
Dewi, K., Sadia, I.W \& Ristiati, N.P. 2013."Pengembangan Perangkat Pembelajaran IPA Terpadu Dengan Setting Inkuiri Terbimbing Untuk Meningkatkan Pemahaman Konsep dan Kinerja Ilmiah Siswa”. EJournal Program Pascasarjana Universitas Pendidikan Ganesa. Vol.3.

Ennis, R.H. 2011. "The Nature Of Critical Thinkingand Creative Thinking”. An Outline of Critical Thinking Disposition and Abilities.

Hamdani, M.A. 2011. Strategi Belajar Mengajar. Bandung: Pustaka Setia.

Kong, Siu Cheung,. Winnie So. \& Wing Mui. 2008.”A Study Of Building A Resource-Based Learning Environment With The Inquiry Learning Approach: Knowledge Of Family Trees". Computers \& Education 50 (2008) 37-60.

Martin, L. \& Hansen. 2002. "Defining Inquiry: Exploring The many Types Of Inquiry In The Science Classroom".

Matthew, B \& Kenneth, I,O. 2013. “A Study On The Effects Of Guided Inquiry Teaching Method On Students Achievement In Logic”. Journal International Researchs. 2(1) No 10, 135-140.

McBride, J.W., Bhatti, M.I., Hannan, M.A \& Feinberg, M. 2012. "Using An Inquiry Approach To Teach Science To Secondary School Science Teachers”. Procedia - Social And Bahavioral Sciences 46 (2012) 2327-2333.

Opara, J.A. \& Oguzor, N.S. 2011. "Inquiry Instruction Method and The School Science Curriculum”. Current Research Journal Of Social Science. 3(3), 188-198.

Rooney, C. 2012. ”How Am I Using Inquiry_Based Learning To Improve 
My Practice And To Encourage Hinger Order Thinking Among My Students Of Mathematics”. Educational Journal of Living Theories. 5(2), 99-127.

Schaal, Steffen., Matt, Monica.,

Grübmeyer \& Sonja. 2012.

Pembelajaran Mobile dan Keanekaragaman Hayati-Mobile Learning and Biodiversity - Bridging the Gap Between Outdoor and Inquiry Learning In PreService Science Teacher Education. Procedia- Social and Behavioral Sciences 46 (2012) 2327 - 2333.

Smaldino, S.E., Lowther, D.L. \& Russell, J.D. 2011. "Instruction Technology \& Media For Learning”. Jakarta: Kencana.

Snyder, L. G \& Snyder., M. J. 2008. "Teaching Critical Thinking And Problem Solving Skill”. The Delta Pi Epsilon Journal. Volume L, No. Spring/Summer. 